\title{
Use of Bio-Based Plastics in the Fruit Supply Chain: An Integrated Approach to Assess Environmental, Economic, and Social Sustainability
}

\author{
Simone Blanc *®), Stefano Massaglia $₫$, Filippo Brun $₫$, Cristiana Peano $₫$, Angela Mosso and \\ Nicole Roberta Giuggioli \\ Department of Agricultural, Forest and Food Sciences (DISAFA), University of Torino, Largo Paolo Braccini 2, \\ 10095 Grugliasco, Italy; stefano.massaglia@unito.it (S.M.); filippo.brun@unito.it (F.B.); \\ cristiana.peano@unito.it (C.P.); angela.mosso@unito.it (A.M.); nicole.giuggioli@unito.it (N.R.G.) \\ * Correspondence: simone.blanc@unito.it; Tel.: +39-011-670-8684
}

Received: 21 March 2019; Accepted: 23 April 2019; Published: 27 April 2019

check for updates

\begin{abstract}
The challenge of developing a sustainable production system includes the reduction of emissions, the efficient use of resources, and the transition to renewable energy. The bioeconomy proposes a development model aimed at reducing impacts and risks associated with the use of non-renewable resources considering the life cycle of products. The European Union is promoting products from renewable sources focused on biochemicals and bio-based plastics, which are high added value products when compared to biofuels. The aim of this paper is to consider sustainability in terms of the environmental, economic, and social aspects of use of bio-based plastics in the fruit chain, considering the case study of raspberry supply chains in northwestern Italy. Different analyses (life-cycle assessment (LCA), life-cycle costing (LCC), and externality assessment (ExA)) were used to assess the impacts along the whole chain by means of an integrated approach. The results show that the bio-based plastic scenario has lower environmental and social impacts than the conventional one, whereas the latter is the best choice according to a classic economic approach. The introduction of bio-based plastics as a replacement for traditional plastics in agri-food chains is the first step toward the use of renewable resources with a low impact on society.
\end{abstract}

Keywords: bio-based materials; green economy; life-cycle assessment; life-cycle costing; social impact

\section{Introduction}

In response to the economic-social-environmental crisis of recent years, a new paradigm is necessary as a driver toward a sustainable processing system and consumption, able to ensure a more balanced and lasting development over time, safeguarding environmental and social aspects [1,2].

From this perspective, the bioeconomy proposes a development model that takes into account the impact and risks associated with the use of non-renewable resources, as well as the life cycle of products and the relationship between production activities and the territory. Currently, these themes are promoted by various intergovernmental programs and organizations, such as the United Nations Environment Program (UNEP), the Organization for Economic Cooperation and Development (OECD), and the World Bank [3-5].

The European Union, within the Europe 2020 strategy, also took the commitment to develop a sustainable economic growth system for the Eurozone [6] and this challenge includes a 30\% reduction of emissions, through the efficient use of resources, the transition to renewable energy, and the fight against poverty and social exclusion. The European Union is the driver of these changes and, in particular, since 2007, promoted some leading markets [7] which, including products from renewable 
sources, were the starting point for what today is known as the bioeconomy strategy [8], aiming for a broader and more sustainable use of renewable resources. This strategy is focused mainly on biochemicals and bio-based plastics, which are products with a high added value, compared to biofuels, and are able to create synergies between companies and research entities.

It is common knowledge that current consumption patterns contribute to the reliance on single-use packaging, where plastic is predominately utilized and, of which, still only $40 \%$ is recycled [9]. In this context, the concept of sustainability in relation to the forms of packaging is increasingly under the spotlight, on the one hand, with regard to the product design stage, which determines a large part of the environmental impact, and, on the other hand, with regard to the choice of materials [10].

According to data from the Institute for Bio-Based Plastics and Biocomposites [11] of the University of Hannover, the global bio-based plastics market is expected to grow in the coming years at a steady rate, reaching an installed production capacity of around 6.2 million tons in the near future, compared to the current 1.4 million tons.

A large part of that production, about 5.1 million tons per year, will be composed of non-biodegradable bio-based plastics, such as green polyethylene (PE) or bio polyethylene terephthalate (PET). The remaining portion, approximately $1 \mathrm{Mt}$, will be represented by biodegradable polymers (in particular polylactic acid (PLA) and polyhydroxyalkanoates (PHAs)), which are currently produced in quantities of around 600,000 tons per year.

Regarding the main areas of development in the production of bio-based plastics, both biodegradable and not, South America and Asia will compete for supremacy, being able to count on rapidly expanding raw material sources and end markets: market shares for the two geographical areas will be, respectively, $44 \%$ and $45.8 \%$, whereas Europe will only account for $6.8 \%$ and North America for $3.4 \%$. European and North American manufacturers and consumers continue to nurture doubts about the processing characteristics and performance of green materials, as well as their costs [12].

In this scenario, Italy plays a leading role, in particular in the biodegradable and compostable bio-based plastic and renewable chemical intermediate sectors, representing an example of "system economics". These sectors make it possible to structure entire fields of application, influencing the methods of production of raw materials and the entire agro-industrial sector downstream, to the point of influencing the methods of consumption and disposal of products [13].

The paradigm shift leading to a post-oil society, with an efficient use of resources, cannot only be promoted by science or technology. In fact, it must be market-valued, respecting, at the same time, economic, environmental, and social sustainability. New knowledge and innovations are essential, but they will not enable Europe to win new markets, as they are unable to generate high-quality jobs or ensure growth and prosperity without a market. Demand-side policies are crucial to support the introduction of bio-products [14]. The concept of sustainability includes several useful methodologies for impact assessment, which can also be used for policy assessment [15]. In this context, life-cycle thinking is a well-known concept widely used to identify impacts along supply chains, in order to compare production and management alternatives. The life-cycle assessment (LCA) is a standardized methodology (ISO 14044:2006) and it is used extensively in the evaluation of environmental impacts in the food supply chain [16]. The evaluation of socio-economic aspects, however, is a more recent advancement in this context.

In particular, the societal life-cycle costing (LCC) method analyses the life-cycle cost of a product or service by identifying environmental externalities and measuring their relative monetary value [17]. It combines the classic analysis of process costs with the evaluation of the so-called externalities, i.e., the environmental costs generated by the company [18] and not considered by the market. Companies need to determine the cost of externalities in relation to the fact that the market is inefficient in evaluating them and, therefore, the resulting price does not reflect the actual value of the assets [19]. Methods to estimate the value of product externalities were previously dealt with in the literature [20]. These mainly refer to the consumption of resources or to the loss of product, due to environmental damage or to the willingness to pay to avoid environmental damage or the costs incurred for prevention; 
in addition, social issues can be evaluated. Despite being a monetary method, the calculation of externalities is in fact an opportunity for the assessment of several social aspects of the system.

Integrated assessment of environmental, economic, and social aspects is taking its first steps and researchers are yet to identify commonly agreed assessment tools. Recently, several authors tried collecting the main works dealing with integrated sustainability assessment according to the triple bottom line concept, analyzing integrated life-cycle tools from different perspectives, related to product design [21], manufacturing [22], agricultural systems [23], and packaging waste management [24]. The authors agreed that, among the various methods, which use qualitative and/or quantitative data, great difficulties in translating the parameters obtained from social evaluations into other studies emerges, thus limiting the comparability of the results.

One possible solution to the intrinsic limits of social assessments is to use monetary assessments to convert social impacts on non-market assets into monetary units; these results can then be compared to each other and to costs and benefits already expressed in monetary units [25].

In recent years, consumption patterns shifted toward quality food, which is safer and tastier and nevertheless obtained through environmentally sustainable practices. It is common knowledge that berry fruits represent a growing market on a large scale worldwide, with an expanding production of approximately 815,000 ha and a total production of around $12 \mathrm{Mt} \cdot y e a r^{-1}$ in 2016 [26]. The management of the supply chain is mainly focused on the topic of sustainability [27]. These fruits need to be sold in packaging due to their high perishability and limited shelf life, and different researches report the use of new green materials for their packaging [28].

With reference to raspberries, in Europe, about 500,000 tons were produced in 2016 [26], the biggest producers being Poland, Serbia, Spain, the Netherlands, and Belgium. Imports also grew from seven to 18 thousand tons per year between 2013 and 2016, especially from Morocco, Mexico, and South Africa. Italian production was equal to $2250 \mathrm{t} \cdot \mathrm{year}^{-1}$ [26] and was concentrated in the northern regions, where Trentino-Alto Adige stood out with $60 \%$ of the total and Piedmont with just under $20 \%$ [29].

Considering the limited studies on the integrated approach to evaluate sustainability in the fresh fruit chain, the aims of this work are twofold: (i) to identify a theoretical framework that combines the three aspects of sustainability with reference to the triple bottom line concept and that helps to overcome the intrinsic limits of social evaluations by converting the social impact into monetary units; (ii) to apply and test the methodological scheme with reference to the use of bio-based materials in the fresh fruit chain, analyzing two different raspberry supply chains in northwestern Italy (Scenario 1, traditional plastic use; Scenario 2, bio-based plastic use).

The approach adopted will make it possible to integrate assessments of environmental performance with the economic and social assessments of the two production, consumption, and disposal options and, at the same time, evaluate the spillover.

\section{Materials and Methods}

\subsection{Theoretical Framework}

The scheme adopted to analyze sustainability follows the triple bottom line approach (TBL) theory [30], which measures supply chain sustainability by distinguishing three aspects: environmental protection, economic performance, and social responsibility [31], as shown in Figure 1. 


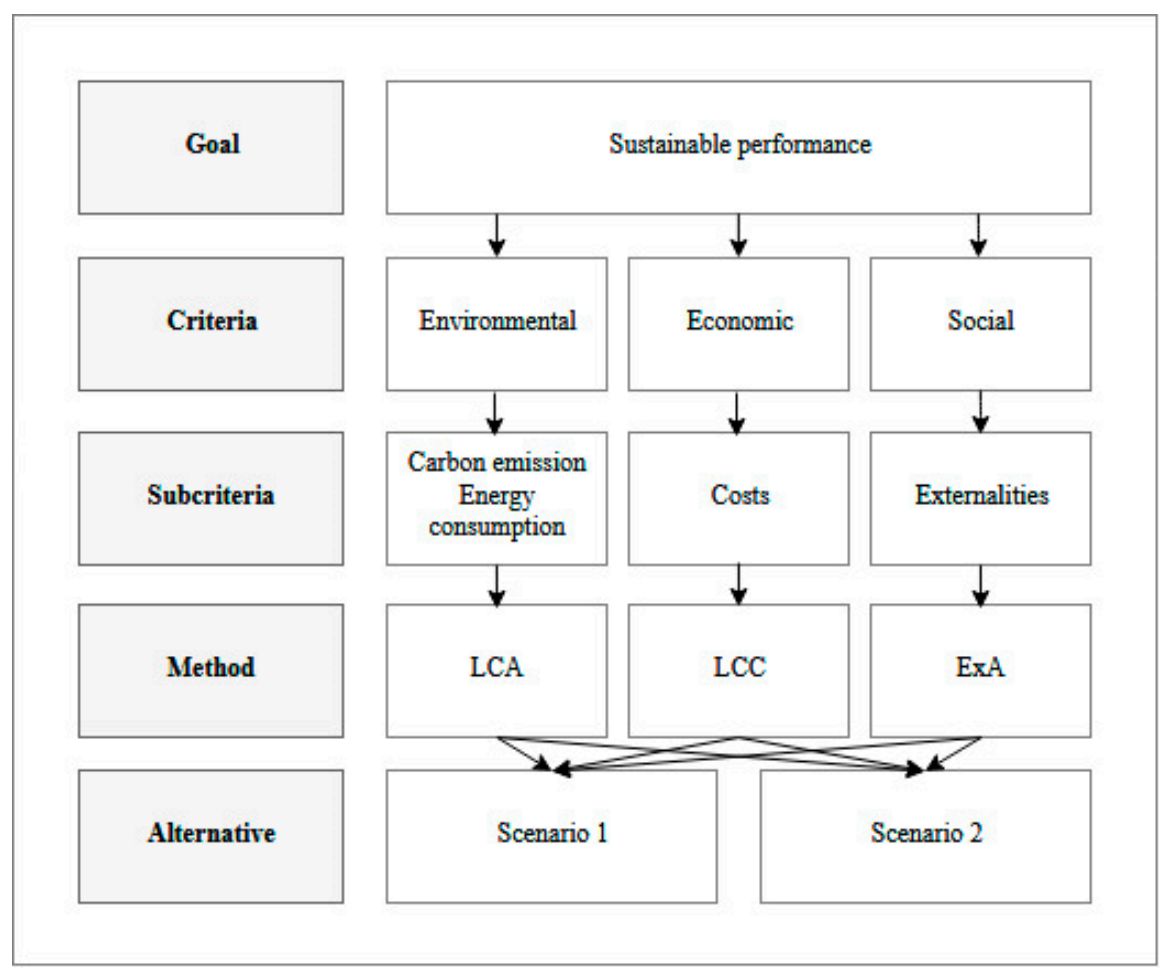

Figure 1. Hierarchical structure of sustainable performance in the raspberry supply chain, modified from Xu et al. [31].

The most popular criterion for assessing environmental performance, widely used for the analysis of traditional and bio-based plastic films [32-34], is the life-cycle assessment (LCA) methodology.

Conversely, there is no commonly acknowledged methodology for conducting economic and social analyses; therefore, as reported by various authors [35,36], an appropriate approach to the context was used for those analyses. As indicated by Groneman et al. [37] and Palsson et al. [38], the economic dimension of sustainability passes through the analysis of the total supply chain cost, using, among others, the methodological scheme called life-cycle costing (LCC) expressed by Gluch and Baumann [39].

In this study, the societal LCC methodology was applied [17], analyzing all costs related to the entire life cycle (from cradle-to-grave) of raspberries: in the first phase, "conventional" costs were considered, followed by an estimate of externalities.

For the social aspect analysis, no specific criteria were defined [31], but several authors examined health and safety among other parameters $[40,41]$. For the assessment of the social impacts of the two examined scenarios, a methodology called externality assessment (ExA) was proposed.

Such a conceptual framework makes it possible to identify a sustainability mindset $[42,43]$ consistent with the TBL scheme that provides a basis to support decision-making on the use of plastic/bio-based plastic products in the agri-food chain. This approach, represented in Figure 2, allows the calculation of potential life-cycle impacts beginning with all the inputs of each phase. The scheme was applied to two scenarios: (S1) scenario referring to the PE (mulch) and PET (packaging) use; (S2) scenario referring to bio-based plastics. 


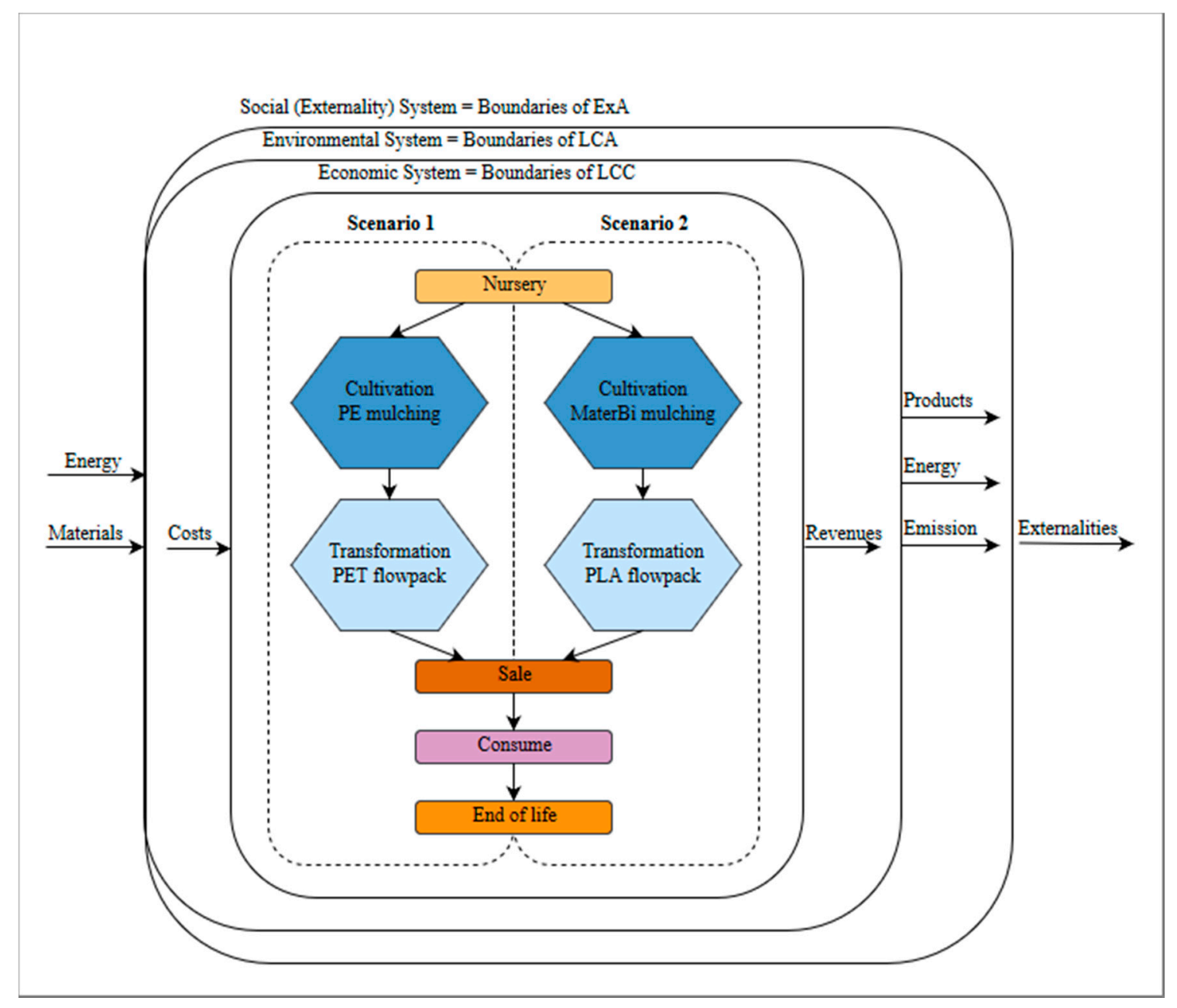

Figure 2. Context and framework.

\subsection{Case Studied}

The raspberry supply chain, developed by the Agricultural Cooperative Agrifrutta (Cuneo, Piedmont, Italy), consists of 200 farms of different sizes (1-5 ha) and composition (4-10 supply chains in each company), situated in hilly and flat terrains of agroecosystems in the Piedmont region. The cooperative manages more than 52 fruit and vegetable products, mainly for Italian and foreign markets. Agrifrutta has two warehouses (one in the foothills area and one on the plains) of about $15,000 \mathrm{~m}^{2}$ with a cooling capacity of about $6500 \mathrm{~m}^{3}$ each, where 72 employees work in the summer period. Thanks to the guidelines for sustainable production, the company adheres to certification programs such as GlobalGAp, BRC, and Organic Production, widely recognized at the global level [44]. The company's development principles include the integration of the supply chain through agreements with Italian and north European distributors, enabling it to overcome market speculation and satisfy the needs of consumers who are attentive to health and environmental issues. In particular, over the years, Agrifrutta specialized in the berry fruit supply chains [27] rapidly expanding its activities in the European market.

\subsection{Life Cycle Inventory and LCA Methodology}

An appropriate approach to calculate environmental impacts is the life-cycle assessment method (LCA), which is a tool internationally referenced as ISO14040. Due to its specificities, which are well suited to the analysis of supply chain behavior from production to final disposal, it is widely used for environmental assessments of fruit and vegetable systems. In many cases, LCA led to the construction 
of a cognitive framework of the total waste generated and of the impact on the environment, comparing products that use different distribution channels (direct sales, large-scale retail chains), or that use different cultivation systems (conventional vs. organic vs. integrated) [44,45]. Other comparison contexts concerned the cultivation techniques (tunnel, open field) [46], the use of alternative transport and packaging systems (both the process and the materials) [47-50], or the different origins of the product (local or imported) [51,52].

After the definition of the two scenarios described above (S1 and S2), a "from cradle-to-grave" approach was followed. The pattern of the process analyzed is shown in Figure 3, while all the input used in the LCA and LCC assessment, broken down by scenario, is summarized in Table 1.

\begin{tabular}{|c|c|c|c|c|c|}
\hline Nursery & Field & Post-harvest & Retailers & Consumers & Landfill \\
\hline $\begin{array}{l}\text { Companies } \\
\text { that provide } \\
\text { the genetic } \\
\text { material to } \\
\text { producers }\end{array}$ & $\begin{array}{c}\text { Producers in } \\
\text { Cuneo } \\
\text { province }\end{array}$ & $\begin{array}{l}\text { Agrifrutta } \\
\text { warehouse } \\
\text { operators }\end{array}$ & $\begin{array}{l}\text { Marketing } \\
\text { partner of } \\
\text { Agrifrutta }\end{array}$ & $\begin{array}{c}\text { Open-air } \\
\text { markets and } \\
\text { mass retail } \\
\text { channels }\end{array}$ & Incineration/recycle \\
\hline
\end{tabular}

Figure 3. Raspberry supply chain framework.

All data related to the raspberry production chain (nursery, field, post-harvest management, retailers, consumers, landfill) refer to the year 2017. Data describing and quantifying the inputs were collected through face-to-face interviews using paper questionnaires completed by the different actors involved in the process.

To analyze the data collected during the inventory phase, SimaPro 7.3 software produced by Pré Consultants was used, and the databases for the inventory used Ecoinvent 2.2 and LCA Food DK.

The data obtained was normalized using mass balance methods, in relation to the initial hypotheses, and was subsequently organized according to two impact categories: global warming potential (GWP) expressed in $\mathrm{kg} \mathrm{CO}_{2 \mathrm{eq}}$, and non-renewable energy (NRE) use (expressed in primary MJ), following other studies that dealt with both the assessment of environmental impact of various bio-based plastics [53], polylactide biopolymers (PLA) [54], and the life cycle of raspberries [55].

The choice of these two categories was related to the need to assess the impact of the two scenarios in relation to the climate changes they could generate, and, at the same time, to provide an overview on energy consumption, which is considered one of the most critical problems in the primary sector [56].

For this representation, a cut-off of $2 \%$ was applied to define the level of environmental significance, and all the data below this percentage value were grouped into the "other" category.

The functional unit for reference purposes was the actual sales package: a $125-\mathrm{g}(9.5 \times 14.5 \times$ $2.5 \mathrm{~cm}$ ) flow pack. Concerning cultivation, we referred to a unit area equal to one hectare. The standard transport distance was then estimated for all the materials used as input, including raw materials (for example, for the plastic film, we also included the shipment of PE granules and the film itself), and the distance was considered from producer to consumer. Finally, it was assumed that all journeys involved a full load. 
Table 1. Life-cycle inventory and costs for the two scenarios. LCA-life-cycle assessment; LCC — life-cycle costing; PE—polyethylene; PVC—polyvinyl chloride; PET—polyethylene terephthalate; PLA-polylactic acid.

\begin{tabular}{|c|c|c|c|c|}
\hline \multirow[t]{2}{*}{ Phase } & \multirow[t]{2}{*}{ Flow or Activity [Unit] } & \multirow{2}{*}{$\begin{array}{c}\text { Input LCA } \\
\text { S1 }\end{array}$} & \multicolumn{2}{|l|}{ Input LCC } \\
\hline & & & S1 & S2 \\
\hline & & Material/Machinery & \multicolumn{2}{|c|}{ Costs } \\
\hline \multirow{5}{*}{ Nursery } & Rooting & Substratum $\left(\mathrm{kg} \mathrm{ha}^{-1}\right)$ & \multicolumn{2}{|c|}{$=$} \\
\hline & Mulching & PE $\left(\mathrm{kg} \mathrm{ha}^{-1}\right)$ & \multicolumn{2}{|c|}{$=$} \\
\hline & Fertigation system & Polyvinyl $\left(\mathrm{kg} \mathrm{ha}^{-1}\right)$ & \multicolumn{2}{|c|}{$=$} \\
\hline & & \multirow{2}{*}{ Compost mix $\left(\mathrm{kg} \mathrm{ha}^{-1}\right)$} & \multicolumn{2}{|c|}{$=$} \\
\hline & & & & \\
\hline \multirow[t]{14}{*}{ Cultivation } & \multirow{2}{*}{$\begin{array}{c}\text { Soil preparation, } \\
\text { planting, management }\end{array}$} & Plough, harrow, and cultivator $\left(\mathrm{h} \mathrm{ha}^{-1}\right)$ & \multicolumn{2}{|c|}{$=$} \\
\hline & & Diesel $\left(1 \mathrm{~h}^{-1}\right)$ & \multicolumn{2}{|c|}{$=$} \\
\hline & \multirow{4}{*}{$\begin{array}{l}\text { Harvest } \\
\text { Irrigation system }\end{array}$} & & \multicolumn{2}{|c|}{$=$} \\
\hline & & $\operatorname{PVC}\left(\mathrm{kg} \mathrm{ha}^{-1}\right)$ & \multicolumn{2}{|c|}{$=$} \\
\hline & & Water $\left(\mathrm{m}^{3} \mathrm{ha}^{-1}\right)$ & \multicolumn{2}{|c|}{$=$} \\
\hline & & Electricity $\left(\mathrm{kWh} \mathrm{ha}^{-1}\right)$ & \multicolumn{2}{|c|}{$=$} \\
\hline & Organic fertilization & Manure $\left(\mathrm{tha}^{-1}\right)$ & \multicolumn{2}{|c|}{$=$} \\
\hline & Mineral fertilization & Compost $\left(\mathrm{t} \mathrm{ha}^{-1}\right)$ & & \\
\hline & Mulching & Materbì $\left(\mathrm{kg} \mathrm{ha}^{-1}\right)$ & $\begin{array}{l}\text { sheet } \\
\text { laying/sheet } \\
\text { removal }\end{array}$ & $\begin{array}{l}\text { only sheet } \\
\text { laying }\end{array}$ \\
\hline & Greenhouse cover & PE $\left(\mathrm{kg} \mathrm{ha}^{-1}\right)$ & & \\
\hline & & Metal $\left(\mathrm{kg} \mathrm{ha}^{-1}\right)$ & & \\
\hline & Hail-proof net & $\mathrm{PE}\left(\mathrm{kg} \mathrm{ha}^{-1}\right)$ & & \\
\hline & Chemical treatment & Active substance $\left(\mathrm{kg} \mathrm{ha}^{-1}\right)$ & & \\
\hline & $\begin{array}{l}\text { Transport from farm gate } \\
\text { to post-harvesting }\end{array}$ & Road transport (km kg) & & \\
\hline Transformation & Refrigeration & Electricity $\left(\mathrm{kWh} \mathrm{kg}^{-1}\right)$ & & \\
\hline & Flow packaging & Electricity $\left(\mathrm{kWh} \mathrm{kg}^{-1}\right)$ & & \\
\hline & & PET tray $\left(\mathrm{g} \mathrm{kg}^{-1}\right) \quad$ PLA tray $\left(\mathrm{g} \mathrm{kg}^{-1}\right)$ & & \\
\hline & & PET wrapping $\left(\mathrm{g} \mathrm{kg}^{-1}\right)$ & & \\
\hline & $\begin{array}{l}\text { Transport from } \\
\text { post-harvesting gate to } \\
\text { point of sale }\end{array}$ & Road transport (km kg) & & \\
\hline Sale & Refrigeration & Electricity $\left(\mathrm{kWh} \mathrm{kg}^{-1}\right)$ & & \\
\hline & Handling & Electricity $\left(\mathrm{kWh} \mathrm{kg}^{-1}\right)$ & & \\
\hline Consumption & Transport & Road transport $\left(\mathrm{km} \mathrm{kg}^{-1}\right)$ & & \\
\hline & Refrigeration & Electricity $\left(\mathrm{kWh} \mathrm{kg}^{-1}\right)$ & & \\
\hline End of life & Disposal & Incineration $20 \%$ /sanitary landfill $80 \%$ & & \\
\hline
\end{tabular}

Note: cost items which do not vary between the two scenarios are indicated by the symbol "="; different cost items are indicated by the symbol " $\neq$ ".

The duration of the nursery phase, considered in the calculation of the life cycle, was one year, whereas the duration of the entire cultivation cycle was 10 years. Therefore, all field operation impacts were weighted against the total lifespan of the plant.

The same procedure was used for the output; the annual production was obtained as a weighted average, considering the whole crop cycle, and was equal to $8.55 \mathrm{t} \cdot \mathrm{ha}^{-1} \cdot \mathrm{year}^{-1}$.

The impact deriving from the production of plastic boxes, used for harvesting and distribution, referred to plastic packaging with collapsible sides; these were excluded from the LCA system boundary, as these containers are reused and fall into a large number of processes.

At the disposal stage, $20 \%$ of plastics were incinerated and the remaining $80 \%$ were disposed of in landfills. The waste product consisted exclusively of the basket with lid and label, as no product leftovers were considered.

\subsection{LCC Methodology}

Conventional costs were calculated for agricultural operations, carried out for each year and for the entire production cycle; to these the costs incurred for product transformation, sales, consumption, and disposal of waste (packaging only) in landfill were added. 
The analyses were carried out using the same functional unit and the same system boundary considered in the LCA analysis.

The cost assessment followed two different approaches. An analytical approach was used for the cultivation, transformation, and sale phases, for which it was possible to gather all the technical and economic data. A parametric approach based on bibliographic information [57] was adopted for the analysis of consumption and the end-of-life.

The cradle-to-grave cost, referred to as $L C C u\left(€ \cdot \mathrm{FU}^{-1}\right)$, was obtained as described in Equation (1).

$$
L C C u=N U+C U+T R+S A+C O+E L
$$

where $L C C u$ is the unitary cost from cradle-to-grave, $N U$ is the cost of nursery, $C U$ is the cost of cultivation, $T R$ is the cost of transformation, $S A$ is the cost of sale, $C O$ is the cost of consumption, and $E L$ is the cost of end-of-life.

The discount rate utilized was $2.5 \%$, applied only to the cultivation phase, and the inflation rate was $0 \%$, in agreement with Gluch and Baumann [39].

In addition, each phase included different types of costs, as described in the following expressions (Equations (2) and (3)):

$$
\begin{gathered}
C U=\mathrm{Mac}+\mathrm{Lab}+\mathrm{MaSe}+(\mathrm{Lb}+\mathrm{In} t) \\
T R, S A=\mathrm{Mac}+\mathrm{Lab}+\mathrm{MaSe}+(\text { Ener }+\mathrm{GE})
\end{gathered}
$$

where Mac is the cost for machinery, Lab is the labor cost, MaSe is the cost of materials and services, $L b$ is the land benefit, Int is the interest on capital, Ener is the cost of energy, and GE is the general expenses.

In the results, the items $L b$ and Int for the $C U$ phase and the items Ener and GE, for the TR and $S A$ phases, were grouped into a single item called "other expenses", as they accounted for less than $10 \%$ of the total cost.

Machinery costs took into account both variable and fixed costs [58] and the labor cost was related to the full cost to the enterprise of an employee [59]. For materials and energy, the market price was used.

Transport referred to the distance traveled from the field to the processing cooperative, then to retail outlets [60].

The internal company factors used in the field phase were evaluated at opportunity cost, considering the remuneration that would have been obtained with an alternative use of the same factor, in comparable and real conditions [61], selecting an interest rate of $2.0 \%$ for tree cultivation and $1.0 \%$ for land use [62].

The processing and sales phases also included general expenses-amounting to $10 \%$ of processing costs (personal communication, Agricultural Cooperative Agrifrutta)—interest on capital, insurance, and business management.

The analysis of consumption included the costs of traveling by car, considering the average distance traveled for household management in Italy [63]; these costs were reported in proportion to the functional unit, in agreement with Pretty [60].

The cost of waste disposal was calculated using the methodology indicated by the National Institute for Environmental Protection and Research (ISPRA) [64], which identifies the unit costs of waste management.

\subsection{ExA-Externality Assessment Methodology}

Many authors stressed the importance of integrating social aspects into LCA, highlighting the role of social impact indicators and the responsibility of all actors involved in the life cycle of products. In this context, they suggested combining the social LCA (S-LCA) method with life-cycle assessments [65].

Considering that S-LCA is a methodology that is still in its infancy and much debated at the academic level, several new indicators and pathways of impact categories are currently proposed, in 
addition to new methods of interpreting the results. In fact, the international scientific community is yet to develop a standardized set of indicators, and different solutions were proposed. In this respect, one of the first was in Jørgensen et al. [66], which developed a matrix structure of indicators for the different impact categories, subdividing them into subcategories, as established by the UNEP/SETAC guidelines [67].

In their contribution to the S-LCA framework, Dreyer, Hauschild, and Schierbeck [68] highlighted that the boundaries of a S-LCA system must be defined in detail, as they are also linked to the impact that each actor of the system can have on the various activities of the production chain.

Other authors, for example, in the wine supply chain, proposed using a simplified version of the analytic hierarchy process (AHP) to measure social sustainability and determine social impact coefficients, based on two selected categories: employment and regional gross domestic product [69].

For the monetary estimate of the effects caused by pollutants, different models are available in literature $[70,71]$, which generally only consider one pollutant factor $[72,73]$ and refer to wide temporal [74] and spatial [75] scales.

Considering the lack of consensus among the various authors regarding the definition of the objectives and aspects of social sustainability assessments, the scientific community identified labor issues, human rights, and health and safety as key aspects of such assessments. In particular, Álvarez-Chávez et al. [76] identified the health and safety aspects to be of primary importance in social assessments concerning bio-based plastics.

In order to avoid the aforementioned problems related to social indicators, in this paper, we proposed a model adapted to our studied context, called ExA (externality assessment), which allowed us to estimate the social costs, caused by the main atmospheric pollutants and referred to the entire life cycle of the studied product, which followed an evaluation strategy that departed from the S-LCA assessments, evaluating only one social aspect. The model followed a logical progression that analyzed each pollutant, from emission to human health damage, using the value of a life year (VOLY) approach and quantifying this damage in economic terms for society.

This method estimated the loss of life expectancy by taking into account lost years of life, respiratory diseases, and other diseases caused by pollutants [77].

The ExA model monetized the negative health effects, mortality, and morbidity, due to the major environmental pollutant $\left(\mathrm{NH}_{3}, \mathrm{NOx}, \mathrm{NMVOC}, \mathrm{PM}\right.$, and $\left.\mathrm{SO}_{2}\right)$ by the value of a life year (VOLY) and the social cost of carbon (SCC) for $\mathrm{CO}_{2}$, as shown in Equation (4).

$$
E x A=E \mathrm{EO}_{2} * \mathrm{SCCO}_{2}+\sum_{i=1}^{6}\left(E P_{i} * \operatorname{VOLYCP} P_{i}\right)
$$

where $E x A$ is the social cost of pollutant and $\mathrm{CO}_{2}\left(€ \cdot \mathrm{FU}^{-1}\right), E C \mathrm{O}_{2}$ denotes emissions of $\mathrm{CO}_{2}\left(\mathrm{~kg} \cdot \mathrm{FU}^{-1}\right)$, $\mathrm{SCCO}_{2}$ is the social cost of carbon $\left(€ \cdot \mathrm{kg}^{-1}\right), E P$ denotes emissions of pollutants $\left(\mathrm{kg} \cdot \mathrm{FU}^{-1}\right)$, VOLYCP is the monetized impact of pollutants on mortality and morbidity $\left(€ \cdot \mathrm{kg}^{-1}\right)$, and $i$ denotes pollutants $i_{1}=$ $\mathrm{NH}_{3}, i_{2}=\mathrm{NO}_{\mathrm{x}}, i_{3}=\mathrm{NMVOC}, i_{4}=\mathrm{PM}_{10}, i_{5}=\mathrm{PM}_{2,5}$, and $i_{6}=\mathrm{SO}_{2}$.

$E \mathrm{EO}_{2}$ and $\mathrm{EP}$ were obtained directly from LCA analyses conducted in this study. $\mathrm{SCCO}_{2}$ is the marginal $\mathrm{CO}_{2}$ abatement cost to contain the average global temperature increase within a $2{ }^{\circ} \mathrm{C}$ range, estimated in agreement with Holland et al. [77] and Nordhaus [73]. VOLYCP was quantified using the VOLY approach identified by Bickel and Friedrick [78], using the monetary values indicated by Holland [77].

\section{Results}

With regard to the selected impact categories, using the LCA approach from cradle-to-grave, Table 2 shows that there are no differences between the two scenarios considered, involving the nursery, sale, consumption, and disposal phases. In both scenarios, the main contribution to GWP and NRE is due to cultivation, transformation, consumption, and disposal phases. Scenario S1 shows 
a higher impact for the cultivation and transformation phases than S2. The overall reduction of potential impacts obtained by shifting to S2 (using bio-based material along all the supply chain) amounts to $12 \%$ considering GWP and $30 \%$ for NRE. This reduction is due to several factors; firstly, considering mulching using bio-based material (Materbi ${ }^{\circledR}$, www.materbi.com) during cultivation, a smaller quantity of raw material is required, thanks to the lower thickness of the film normally used. Furthermore, no removal and disposal are necessary due to its capacity to biodegrade into the soil.

Table 2. LCA and LCC results.

\begin{tabular}{ccccccccr}
\hline & \multicolumn{2}{c}{ GWP } & \multicolumn{2}{c}{ NRE } & \multicolumn{2}{c}{ Costs } & \multicolumn{2}{c}{ Externalities } \\
\hline & \multicolumn{2}{c}{$\mathrm{kg} \mathrm{CO}$ 2eq } & \multicolumn{2}{c}{ MJ primary } & $€ \cdot \mathrm{FU}^{-1}$ & & $€ \cdot \mathrm{FU}^{-1}$ \\
\hline S1 & $\mathrm{S} 2$ & $\mathrm{~S} 1$ & $\mathrm{~S} 2$ & $\mathrm{~S} 1$ & $\mathrm{~S} 2$ & $\mathrm{~S} 1$ & $\mathrm{~S} 2$ \\
\hline Nursery & 0.0054 & 0.0054 & 0.4896 & 0.4896 & 0.0121 & 0.0121 & 0.00019 & 0.00015 \\
Cultivation & 0.1525 & 0.1058 & 3.5017 & 1.9637 & 0.5419 & 0.5413 & 0.00690 & 0.00554 \\
Transformation & 0.1935 & 0.1692 & 5.0854 & 2.9894 & 0.6144 & 0.7541 & 0.00622 & 0.00382 \\
Sale & 0.0893 & 0.0893 & 1.3260 & 1.3260 & 0.0409 & 0.0409 & 0.02243 & 0.01802 \\
Consumption & 0.1350 & 0.1350 & 1.8870 & 1.8870 & 0.0045 & 0.0045 & 0.04239 & 0.03406 \\
End-of-life & 0.0318 & 0.0318 & 0.0253 & 0.0253 & 0.0014 & 0.0014 & 0.00035 & 0.00028 \\
\hline Total & $\mathbf{0 . 6 0 7 5}$ & $\mathbf{0 . 5 3 6 6}$ & $\mathbf{1 2 . 3 1 5 0}$ & $\mathbf{8 . 6 8 1 0}$ & $\mathbf{1 . 2 1 5 4}$ & $\mathbf{1 . 3 5 4 5}$ & $\mathbf{0 . 0 7 8 5 0}$ & $\mathbf{0 . 0 6 1 9 0}$ \\
\hline
\end{tabular}

In terms of LCC results, S1 has a "cradle-to-grave" cost that is 11\% lower than S2. In both cases, transformation is the most important step, accounting for 51\% of total costs in $\mathrm{S} 1$ and $56 \%$ in S2. In the latter case, the increase in costs is due to the use of the biodegradable container, which costs $14 €$ cent more than the traditional PE container.

When the costs for cultivation, which are the second most important costs, are added to the transformation costs, the expenditure rises to $1.16 € \cdot \mathrm{UF}^{-1}$ for S1 and $1.29 € \cdot \mathrm{UF}^{-1}$ for S2, equal to more than $95 \%$ of the total costs. The other phases have a minimal contribution to the life-cycle cost of the product, which is $6 €$ cent $\cdot \mathrm{UF}^{-1}$ for both scenarios considered.

When looking at the results by type of cost (Table 3), labor represents more than half of the costs for both scenarios and is almost exclusively concentrated in the cultivation and processing phases. The second largest item is materials, which accounts for one-fifth of total costs in S1 and just under one-third in S2. For the latter, the bio-based plastic container represents $14 \%$ of the total costs, while the Materbi ${ }^{\circledR}$ mulching material has a lower cost compared to the traditional PE film used in S1. In S1, the use of PE film accounts for only $5 \%$ of the overall costs.

Table 3. Distribution of costs by type for the two scenarios.

\begin{tabular}{|c|c|c|c|c|c|c|c|c|c|}
\hline & & \multicolumn{2}{|c|}{ S1 } & \multicolumn{4}{|c|}{ S2 } & $\%$ & \\
\hline Machinery & & 0.1643 & & $13.5 \%$ & & 0.1643 & & $12.1 \%$ & \\
\hline Materials and services & & 0.2531 & & $20.8 \%$ & & 0.3797 & & $28.0 \%$ & \\
\hline & Mulching & & 0.0022 & & $0.18 \%$ & & 0.0018 & & $0.13 \%$ \\
\hline & Plastic flow pack & & 0.0630 & & $5.18 \%$ & & 0.1900 & & $14.03 \%$ \\
\hline Total & & 1.2154 & & $100 \%$ & & 1.3545 & & $100 \%$ & \\
\hline
\end{tabular}

From the estimate of externalities, it can be observed that, by changing only two inputs related to mulching and type of packaging, significant results are produced: the cost of externalities is equal to $0.0785 € \cdot \mathrm{UF}^{-1}$ for S1, while it drops to $0.0619 € \cdot \mathrm{UF}^{-1}(-21 \%)$ for S2. For both scenarios, more than $80 \%$ of externalities are generated in the sales and consumption phases, where the emissions that determine the greatest impact on health are those related to the refrigeration and then transport of the container by car. 
In both scenarios, up to $99 \%$ of environmental costs are related to emissions that contribute to climate change $\left(\mathrm{CO}_{2}\right)$ and have local health impacts, such as $\mathrm{NMVOC}, \mathrm{PM}_{10}$, and $\mathrm{SO}_{2}$. The other pollutants, ammonia, nitrogen oxides, heavy metals, and organic pollutants, contribute only to the remaining $1 \%$.

The formulation of the sustainability analysis according to the TBL approach can be summarized in a single graph (Figure 4), which allows the results obtained from the application of the three methods to be compared.

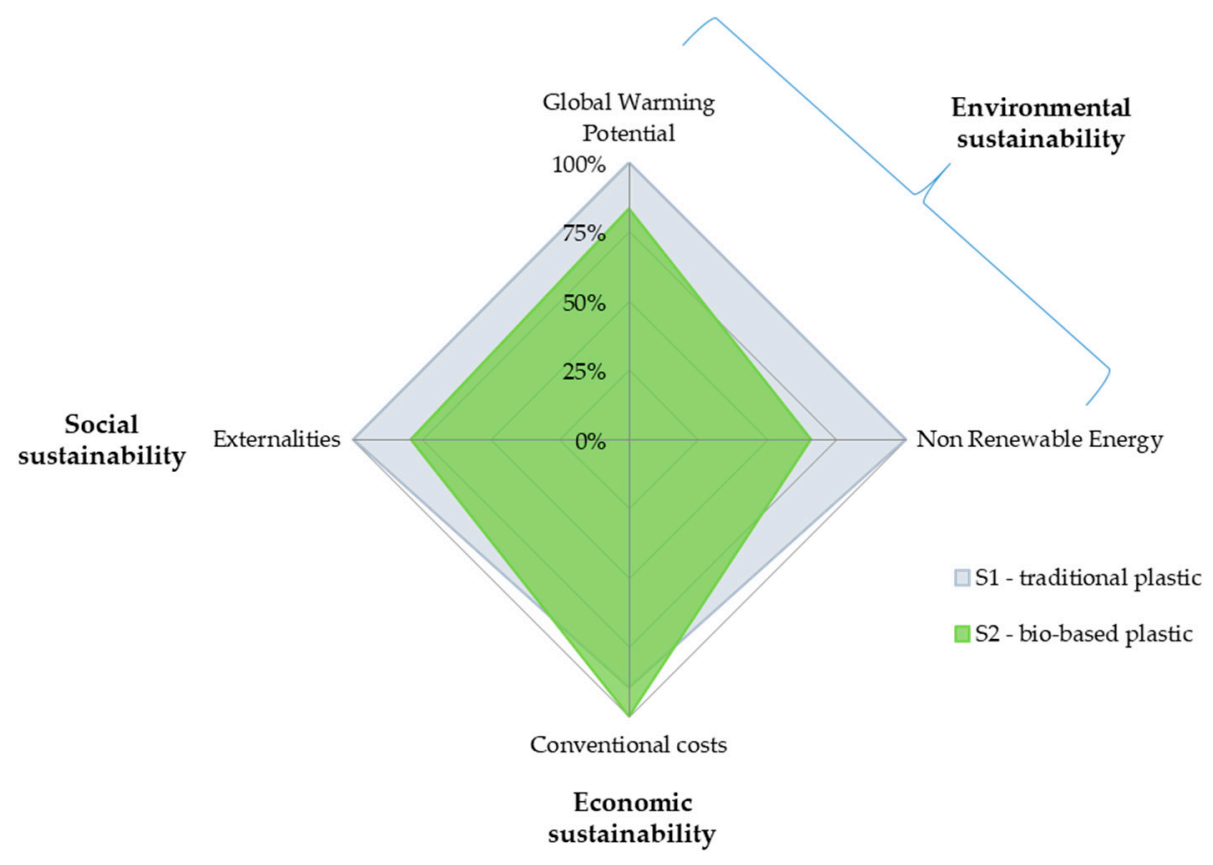

Figure 4. Sustainable performance results according to the triple bottom line (TBL) approach.

S1 strongly contributes to environmental and social impacts, while S2 is more conservative and has less impact on human health. By contrast, the latter shows conventional costs over its entire life cycle $10 \%$ higher than the former.

Therefore, S2 can be considered, on the whole, better than S1 in terms of environmental and social sustainability, while $\mathrm{S} 1$ is the best choice according to a traditional economic approach.

\section{Discussion}

As is widely acknowledged, agri-food production has environmental impacts on a global scale [79] and it is, therefore, desirable to adopt less impactful strategies, in addition to evaluating the costs that more environmentally friendly solutions can entail.

From an environmental point of view, the LCA analysis allowed us to underline how about half of the impact, intended as a contribution to global warming, can be traced back to the field phase. The measures adopted in the sustainable scenario allow a one-fifth reduction in emissions, showing the high potential of this supply chain with regard to environmental aspects.

Despite these encouraging results, one must also consider the indications of other authors [80], who reported the negative effects that the biodegradable mulch film residues can have in the soil-plant system, compared with PE mulch film.

The use of bio-based plastics such as Materbi ${ }^{\circledR}$ in the field phase could be positive to maintain a higher moisture value percentage in the soil when compared to traditional materials. Thanks to this property, the moisture retained in the soil allows some important results to be obtained in terms of growth of raspberry plants (number of shoots and their height) [81]. The improvement of these features will also presumably increase the berry production of each plant. 
On the contrary, when considering the use of bio-based materials in the transformation phase (packaging), it is commonly acknowledged that this provides the opportunity to improve the shelf life of berries, also limiting their weight losses (important criteria for fruit marketability) and the waste of products. In fact, the PLA clamshell prolongs the post-harvest life of blueberries at different temperatures [82].

Nevertheless, the landfill waste management phase remains relevant and, as also indicated by other authors [83], the incineration and recycling phase needs to be replaced by composting and anaerobic digestion.

As other authors also pointed out $[84,85]$, polylactic acid (PLA) products have great potential to permeate the polymer market, as they are compostable, in addition to being technically recyclable; however, a limited number of infrastructures are able to carry out these activities, both locally and globally.

As far as the methods used are concerned, the examination of conventional costs used well-established practices typical of the discipline of business accounting [86]; on the other hand, a synthetic method was chosen for the analysis of externalities, which did not require adaptations and enabled immediate implementation.

In this respect, the numerous limitations of LCC processing must be taken into account. In fact, these valuations are often imprecise, due to the many assumptions and estimates that cannot be ignored [39]. In view of this limitation, it should be noted that, in the examined case, all costs and technical data from cradle to point-of-sale were collected directly, minimizing the margin of error, while the data used for the analysis of the consumption and end-of-life phases were derived from bibliography and in particular from research institutes, which guaranteed a high degree of reliability.

The economic results show that the transition toward a more sustainable supply chain involves an increase in costs, both in the cultivation phase and in the processing phase. Moreover, this increase is not currently reflected in a different sales price, since the products of the two techniques are not distinguishable by the consumer. Currently, consumers often believe that the impact of fruit production is limited to the initial stage of production and believe that organic labeling is sufficient to exert pressure to improve the environmental impact, while neglecting all the subsequent stages of processing, marketing, consumption, and disposal. Other studies [87] showed consumer interest in the preference to purchase compostable polymer packaging because they are aware of its sustainability, confirming the market interest in these products.

As pointed out by Spierling et al. [53], few studies concerning the economic aspects of bio-based plastics were published to date and, therefore, comparability is difficult. In general, authors agree that traditional plastics reveal lower costs than "innovative" bio-based products [88]. The high price of bio-based plastics is currently a competitive disadvantage when compared to traditional products, which limits their production on a large scale. However, it should be borne in mind that the bio-based plastic industry is in its infancy and is developing rapidly, also ensuring greater production efficiency. Additionally, the greater propensity of the consumer toward bio-based products will lead over the years to a progressive increase in demand with a desirable alignment of the prices of these products compared to traditional plastics.

Another aspect, linked to the social costs caused by polluting emissions, presents some points for discussion, regarding the search for supply chain strategies and the adoption of new materials capable of creating more sustainable products. However, as also argued by some authors, who developed the techniques used in this article for evaluating externalities [77], these methods still have rather serious limitations and incorporate a high degree of subjectivity.

The study presented here cannot be configured as S-LCA, as it does not follow the classic evaluation rules and indicators, identified by Benoit-Norris et al. [89], and the results are not directly comparable with those of other studies that analyzed the social aspects of bio-based fuels and chemicals [53].

However, we tried to identify a tool to assess the social costs related to human health in a society in transition from the use of traditional plastics to the use of bio-based plastics, where it emerged 
from several authors $[90,91]$ that the main issue is the serious problems related to human health. Underlining the conceptual nature of the approach presented here, it is worth remembering that the categories and indicators we propose represent a starting point that requires future adaptations and further applications, as also indicated by other authors [17].

In the future, the proposed method must be implemented to obtain a comprehensive assessment, in order to quantify other forms of impact, both on ecosystems and the damage to cultural heritage, caused by acid deposits and the contribution to the hole in the ozone layer. Moreover, the proposed methodology does not allow to quantify the social costs of pollutants for different categories of stakeholders; this limitation may be overcome in the future by integrating other indicators that cannot be monetized, but that must be included to obtain a harmonized assessment, allowing more information to be collected. Following Sala et al. [15], this study, by comparing two different raspberry supply chains, intended to propose a methodological solution-oriented approach that, through integration and coproduction of knowledge from different disciplines and actors, leads to the analysis of options and participated solutions. The integrated assessment proposed brings together different categories of impacts, biophysical and socio-economic, through a horizontal integration and allows the results to be utilized in decision-making processes.

\section{Conclusions}

This paper provides a methodological framework for identifying and quantifying the environmental, economic, and social impacts related to the use of plastics in the agro-food chain. The methodology was applied to the case of the raspberry chain, which is an important segment of the fresh berry market, witnessing an ever-increasing demand, whereby the product necessitates protective packaging to ensure sealability.

The proposed methodology uses a model that lends itself well to support policy-makers at the political level, decision-makers at the company level, and consumers in their choices, providing information that is readable and comprehensible.

It is interesting to underline how, in a recent intercultural study [92], it emerged that consumers base their assessment of the eco-compatibility of packaging mainly on criteria related to its end-of-life and biodegradability, where reusability and recyclability are considered. Faced with the choice between a non-biodegradable container based on renewable resources or a biodegradable container based on non-renewable resources (fossil fuels), in many cases, the consumer chooses the latter.

In our study case, it is evident that the success of the adoption of bio-based material, instead of the traditionally used plastics (PE and PET), is linked to the ability to operate in a systemic way along the supply chain. This means that consumers must be able to recognize the different impact on the environment, for example, through the adoption of certifications or brands that allow price differentiation compared to traditional products, compensating for higher production costs. For example, recent research from the University of Wageningen showed that consumers want precise indications of how to handle packaging after use [93]. The packaging must always contain clear information on how to dispose of the materials and how to recycle them.

The future developments of our research may concern the study of forms of global sustainable management, capable of involving all the actors of a "plastic packaging system", with the aim of creating a circular economy scheme that includes all phases from design to disposal. For this perspective to be implemented, it is necessary to engage not only producers and consumers, but also policy-makers capable of implementing incentive policies and awareness-raising campaigns to overcome current cultural barriers.

Author Contributions: Conceptualization, S.B.; methodology Section 2.1, Section 2.4, and Section 2.5, S.B.; methodology Sections 2.2 and 2.3, N.R.G.; validation, S.M., F.B., C.P., and A.M.; formal analysis, S.B.; writing-original draft preparation, S.B., S.M., F.B., C.P., A.M., and N.R.G.; writing-review and editing, S.B.; supervision, A.M.; project administration, C.P.; funding acquisition, C.P. 
Funding: This work was conducted with the financial support of Piedmont Region-Agrofood Platform F\&F bio pack project.

Conflicts of Interest: The authors declare no conflicts of interest.

\section{References}

1. The World Bank. Investors Welcome Newly Released World Bank Green Bond Impact Report. Available online: http://www.worldbank.org/en/news/feature/2015/08/11/investors-welcome-world-bank-green-bondimpact-report (accessed on 22 February 2019).

2. Schwartz, P. International financial institutions and biodiversity conservation. In Biodiversity and Nature Protection Law; Edward Elgar Publishing: Cheltenham, UK, 2017; pp. 399-412.

3. Jolly, R.; Ray, D.B. Human security-National perspectives and global agendas: Insights from national human development reports. J. Int. Dev. 2007, 19, 457-472. [CrossRef]

4. OECD. Towards Green Growth; Secretary-General of the OECD, Ed.; OECD Publishing: Paris, France, 2011; ISBN 9789264094970.

5. The World Bank. Inclusive Green Growth; The World Bank: Washington, DC, USA, 2012; ISBN 978-0-8213-9551-6.

6. European Commission. Europe 2020 A Strategy for a Smart, Sustainable and Inclusive Growth (COM-2010, 2020 Final). Available online: https://www.eea.europa.eu/policy-documents/com-2010-2020-europe-2020 (accessed on 19 April 2019).

7. European Commission. A Lead Market Initiative for Europe-European Environment Agency. Available online: https://www.eea.europa.eu/policy-documents/a-lead-market-initiative-for-europe (accessed on 20 March 2019).

8. European Commission. Innovating for Sustainable Growth: A Bioeconomy for Europe-COM (2012). Available online: https://ec.europa.eu/research/bioeconomy/pdf/official-strategy_en.pdf (accessed on 19 April 2019).

9. United Nations Environment Programme. Single-Use Plastics: A Roadmap for Sustainability. Available online: http://wedocs.unep.org/handle/20.500.11822/25496 (accessed on 19 February 2019).

10. Kulatunga, A.K.; Karunatilake, N.; Weerasinghe, N.; Ihalawatta, R.K. Sustainable manufacturing based decision support model for product design and development process. Procedia CIRP 2015, 26, 87-92. [CrossRef]

11. Institute for Bioplastics and Biocomposites. Information on Bioplastic. Available online: https://www.ifbbhannover.de/en/. (accessed on 19 April 2019).

12. Lettner, M.; Schöggl, J.-P.; Stern, T. Factors influencing the market diffusion of bio-based plastics: Results of four comparative scenario analyses. J. Clean. Prod. 2017, 157, 289-298. [CrossRef]

13. Cluster Spring. Sustainable Processes and Resources for Innovation and National Growth. Available online: http://www.clusterspring.it (accessed on 22 February 2019).

14. Clark, J.H.; Farmer, T.J.; Herrero-Davila, L.; Sherwood, J. Circular economy design considerations for research and process development in the chemical sciences. Green Chem. 2016, 18, 3914-3934. [CrossRef]

15. Sala, S.; Farioli, F.; Zamagni, A. Progress in sustainability science: Lessons learnt from current methodologies for sustainability assessment: Part 1. Int. J. Life Cycle Assess. 2013, 18, 1653-1672. [CrossRef]

16. Vinyes, E.; Asin, L.; Alegre, S.; Muñoz, P.; Boschmonart, J.; Gasol, C.M. Life cycle assessment of apple and peach production, distribution and consumption in Mediterranean fruit sector. J. Clean. Prod. 2017, 149, 313-320. [CrossRef]

17. Neugebauer, S.; Forin, S.; Finkbeiner, M. From life cycle costing to economic life cycle assessment-introducing an economic impact pathway. Sustainability 2016, 8, 428. [CrossRef]

18. Bovea, M.D.; Vidal, R. Increasing product value by integrating environmental impact, costs and customer valuation. Resour. Conserv. Recycl. 2004, 41, 133-145. [CrossRef]

19. Craighill, A.; Powell, J.C. A Lifecycle Assessment and Evaluation of Construction and Demolition Waste; Working Paper-Centre for Social and Economic Research on the Global Environment; University of East Anglia: Norwich, UK, 1999; pp. 1-52. 
20. Vogtländer, J.G.; Brezet, H.C.; Hendriks, C.F. The virtual Eco-costs '99: A single LCA-based indicator for sustainability and the Eco-costs-Value ratio (EVR) model for economic allocation: A new LCA-based calculation model to determine the sustainability of products and services. Int. J. Life Cycle Assess. 2001, 6, 157-166. [CrossRef]

21. Ahmad, S.; Wong, K.Y.; Tseng, M.L.; Wong, W.P. Sustainable product design and development: A review of tools, applications and research prospects. Resour. Conserv. Recycl. 2018, 132, 49-61. [CrossRef]

22. Bradley, R.; Jawahir, I.S.; Badurdeen, F.; Rouch, K. A total life cycle cost model (TLCCM) for the circular economy and its application to post-recovery resource allocation. Resour. Conserv. Recycl. 2018, 135, 141-149. [CrossRef]

23. Mancuso, T.; Verduna, T.; Blanc, S.; Di Vita, G.; Brun, F. Environmental sustainability and economic matters of commercial types of common wheat. Agric. Econ. (Zemědělská Ekon) 2019, 65, 194-202. [CrossRef]

24. Ferrão, P.; Ribeiro, P.; Rodrigues, J.; Marques, A.; Preto, M.; Amaral, M.; Domingos, T.; Lopes, A.; Costa, E.I. Environmental, economic and social costs and benefits of a packaging waste management system: A Portuguese case study. Resour. Conserv. Recycl. 2014, 85, 67-78. [CrossRef]

25. Edwards, J.; Burn, S.; Crossin, E.; Othman, M. Life cycle costing of municipal food waste management systems: The effect of environmental externalities and transfer costs using local government case studies. Resour. Conserv. Recycl. 2018, 138, 118-129. [CrossRef]

26. FAOSTAT. Faostat Database. Available online: http://www.fao.org/faostat (accessed on 22 February 2019).

27. Peano, C.; Girgenti, V.; Baudino, C.; Giuggioli, N.R. Blueberry supply chain in Italy: Management, innovation and sustainability. Sustainability 2017, 9, 261. [CrossRef]

28. Giuggioli, N.R.; Girgenti, V.; Peano, C. Qualitative performance and consumer acceptability of starch films for the blueberry modified atmosphere packaging storage. Pol. J. Food Nutr. Sci. 2017, 67, 129-136. [CrossRef]

29. Blanc, S.; Accastello, C.; Girgenti, V.; Brun, F.; Mosso, A. Innovative strategies for the raspberry supply chain: An environmental and economic assessment. Qual. Access Success 2018, 19, 139-142.

30. Elkington, J. Partnerships from cannibals with forks: The triple bottom line of 21st-century business. Environ. Qual. Manag. 1998, 8, 37-51. [CrossRef]

31. Xu, J.; Jiang, X.; Wu, Z. A sustainable performance assessment framework for plastic film supply chain management from a chinese perspective. Sustainability 2016, 8, 1042. [CrossRef]

32. Toniolo, S.; Mazzi, A.; Niero, M.; Zuliani, F.; Scipioni, A. Comparative LCA to evaluate how much recycling is environmentally favourable for food packaging. Resour. Conserv. Recycl. 2013, 77, 61-68. [CrossRef]

33. Leceta, I.; Etxabide, A.; Cabezudo, S.; De La Caba, K.; Guerrero, P. Bio-based films prepared with by-products and wastes: Environmental assessment. J. Clean. Prod. 2014, 64, 218-227. [CrossRef]

34. Siracusa, V.; Ingrao, C.; Lo Giudice, A.; Mbohwa, C.; Dalla Rosa, M. Environmental assessment of a multilayer polymer bag for food packaging and preservation: An LCA approach. Food Res. Int. 2014, 62, 151-161. [CrossRef]

35. Mohamad, R.S.; Verrastro, V.; Cardone, G.; Bteich, M.R.; Favia, M.; Moretti, M.; Roma, R. Optimization of organic and conventional olive agricultural practices from a life cycle assessment and life cycle costing perspectives. J. Clean. Prod. 2014, 70, 78-89. [CrossRef]

36. Falcone, G.; De Luca, A.I.; Stillitano, T.; Strano, A.; Romeo, G.; Gulisano, G. Assessment of environmental and economic impacts of vine-growing combining life cycle assessment, life cycle costing and multicriterial analysis. Sustainability 2016, 8, 793. [CrossRef]

37. Grönman, K.; Soukka, R.; Järvi-Kääriäinen, T.; Katajajuuri, J.-M.; Kuisma, M.; Koivupuro, H.-K.; Ollila, M.; Pitkänen, M.; Miettinen, O.; Silvenius, F.; et al. Framework for sustainable food packaging design. Packag. Technol. Sci. 2013, 26, 187-200. [CrossRef]

38. Pålsson, H.; Finnsgård, C.; Wänström, C. Selection of packaging systems in supply chains from a sustainability perspective: The case of volvo. Packag. Technol. Sci. 2013, 26, 289-310. [CrossRef]

39. Gluch, P.; Baumann, H. The life cycle costing (LCC) approach: A conceptual discussion of its usefulness for environmental decision-making. Build. Environ. 2004, 39, 571-580. [CrossRef]

40. Boukherroub, T.; Ruiz, A.; Guinet, A.; Fondrevelle, J. An integrated approach for sustainable supply chain planning. Comput. Oper. Res. 2015, 54, 180-194. [CrossRef]

41. Matos, S.; Hall, J. Integrating sustainable development in the supply chain: The case of life cycle assessment in oil and gas and agricultural biotechnology. J. Oper. Manag. 2007, 25, 1083-1102. [CrossRef] 
42. Csiszar, S.A.; Meyer, D.E.; Dionisio, K.L.; Egeghy, P.; Isaacs, K.K.; Price, P.S.; Scanlon, K.A.; Tan, Y.-M.; Thomas, K.; Vallero, D.; et al. Conceptual framework to extend life cycle assessment using near-field human Exposure modeling and high-throughput tools for chemicals. Environ. Sci. Technol. 2016, 50, 11922-11934. [CrossRef]

43. Gong, J.; You, F. Consequential life cycle optimization: General conceptual framework and application to algal renewable diesel production. ACS Sustain. Chem. Eng. 2017, 5, 5887-5911. [CrossRef]

44. Baroni, L.; Cenci, L.; Tettamanti, M.; Berati, M. Evaluating the environmental impact of various dietary patterns combined with different food production systems. Eur. J. Clin. Nutr. 2007, 61, 279-286. [CrossRef]

45. Wood, R.; Lenzen, M.; Dey, C.; Lundie, S. A comparative study of some environmental impacts of conventional and organic farming in Australia. Agric. Syst. 2006, 89, 324-348. [CrossRef]

46. Cellura, M.; Longo, S.; Mistretta, M. Life cycle assessment (LCA) of protected crops: An italian case study. J. Clean. Prod. 2012, 28, 56-62. [CrossRef]

47. Albrecht, S.; Brandstetter, P.; Beck, T.; Fullana-i-Palmer, P.; Grönman, K.; Baitz, M.; Deimling, S.; Sandilands, J.; Fischer, M. An extended life cycle analysis of packaging systems for fruit and vegetable transport in Europe. Int. J. Life Cycle Assess. 2013, 18, 1549-1567. [CrossRef]

48. Gallego-Schmid, A.; Mendoza, J.M.F.; Azapagic, A. Improving the environmental sustainability of reusable food containers in Europe. Sci. Total Environ. 2018, 628, 979-989. [CrossRef] [PubMed]

49. Levi, M.; Cortesi, S.; Vezzoli, C.; Salvia, G. A comparative life cycle assessment of disposable and reusable packaging for the distribution of italian fruit and vegetables. Packag. Technol. Sci. 2011, 24, 387-400. [CrossRef]

50. Singh, S.P.; Chonhenchob, V.; Singh, J. Life cycle inventory and analysis of re-usable plastic containers and display-ready corrugated containers used for packaging fresh fruits and vegetables. Packag. Technol. Sci. 2006, 19, 279-293. [CrossRef]

51. Payen, S.; Basset-Mens, C.; Perret, S. LCA of local and imported tomato: An energy and water trade-off. J. Clean. Prod. 2015, 87, 139-148. [CrossRef]

52. Webb, J.; Williams, A.G.; Hope, E.; Evans, D.; Moorhouse, E. Do foods imported into the UK have a greater environmental impact than the same foods produced within the UK? Int. J. Life Cycle Assess. 2013, 18, 1325-1343. [CrossRef]

53. Spierling, S.; Knüpffer, E.; Behnsen, H.; Mudersbach, M.; Krieg, H.; Springer, S.; Albrecht, S.; Herrmann, C.; Endres, H.-J. Bio-based plastics-A review of environmental, social and economic impact assessments. J. Clean. Prod. 2018, 185, 476-491. [CrossRef]

54. Vink, E.T.H.; Davies, S. Life cycle inventory and impact assessment data for 2014 Ingeo ${ }^{\circledR}$ polylactide production. Ind. Biotechnol. 2015, 11, 167-180. [CrossRef]

55. Girgenti, V.; Peano, C.; Bounous, M.; Baudino, C. A life cycle assessment of non-renewable energy use and greenhouse gas emissions associated with blueberry and raspberry production in northern Italy. Sci. Total Environ. 2013, 458, 414-418. [CrossRef]

56. Baudino, C.; Giuggioli, N.R.; Briano, R.; Massaglia, S.; Peano, C. Integrated methodologies (SWOT, TOWS, LCA) for improving production chains and environmental sustainability of kiwifruit and baby kiwi in Italy. Sustainability 2017, 9, 1621. [CrossRef]

57. Rivera, X.C.S.; Azapagic, A. Life cycle costs and environmental impacts of production and consumption of ready and home-made meals. J. Clean. Prod. 2016, 112, 214-228. [CrossRef]

58. Sierra-Pérez, J.; García-Pérez, S.; Blanc, S.; Boschmonart-Rives, J.; Gabarrell, X. The use of forest-based materials for the efficient energy of cities: Environmental and economic implications of cork as insulation material. Sustain. Cities Soc. 2018, 37, 628-636. [CrossRef]

59. Blanc, S.; Brun, F.; Di Vita, G.; Mosso, A. Traditional beekeeping in rural areas: Profitability analysis and feasibility of pollination service. Qual. Access Success 2018, 19, 72-79.

60. Pretty, J.N.; Ball, A.S.; Lang, T.; Morison, J.I.L. Farm costs and food miles: An assessment of the full cost of the UK weekly food basket. Food Policy 2005, 30, 1-19. [CrossRef]

61. Brun, F.; Mosso, A. Production costs and profitability of blueberry cultivation (in Italian). Dendronatura 2013, 34, 77-85.

62. Brun, F.; Mosso, A. Comparison of profitability of raspberry cultivars (in Italian). Dendronatura 2014, 35, 76-82. 
63. Observatory on the Mobility Behaviour of Italians. Italians' Demand for Mobility-Economic Report at the end of the Year; National Communications Foundation: Rome, Italy, 2015.

64. ISPRA. Municipal Waste Report. Available online: http://www.isprambiente.gov.it/it (accessed on 17 November 2018).

65. Sanchez Ramirez, P.K.; Petti, L. Social life cycle assessment: Methodological and implementation issues. USV Ann. Econ. Public Adm. 2011, 11, 11-17.

66. Jørgensen, A.; Le Bocq, A.; Nazarkina, L.; Hauschild, M. Methodologies for social life cycle assessment. Int. J. Life Cycle Assess. 2008, 13, 96-103. [CrossRef]

67. Andrews, E.S. Guidelines for Social Life Cycle Assessment of Products; UNEP/Earthprint: London, UK, 2010.

68. Dreyer, L.; Hauschild, M.; Schierbeck, J. A Framework for Social Life Cycle Impact Assessment (10 pp). Int. J. Life Cycle Assess. 2006, 11, 88-97. [CrossRef]

69. Varsei, M.; Polyakovskiy, S. Sustainable supply chain network design: A case of the wine industry in Australia. Omega 2017, 66, 236-247. [CrossRef]

70. De Luca, A.I.; Iofrida, N.; Leskinen, P.; Stillitano, T.; Falcone, G.; Strano, A.; Gulisano, G. Life cycle tools combined with multi-criteria and participatory methods for agricultural sustainability: Insights from a systematic and critical review. Sci. Total Environ. 2017, 595, 352-370. [CrossRef]

71. Watkiss, P. Aggregate economic measures of climate change damages: Explaining the differences and implications. Wiley Interdiscip. Rev. Clim. Chang. 2011, 2, 356-372. [CrossRef]

72. Dietz, S. The treatment of risk and uncertainty in the US social cost of carbon for regulatory impact analysis. Economics 2012, 6, 1-12. [CrossRef]

73. Nordhaus, W.D. Revisiting the social cost of carbon. Proc. Natl. Acad. Sci. USA 2017, 114, 1518-1523. [CrossRef]

74. Lu, X.; Yao, T.; Fung, J.C.H.; Lin, C. Estimation of health and economic costs of air pollution over the Pearl River Delta region in China. Sci. Total Environ. 2016, 566-567, 134-143. [CrossRef]

75. Waldhoff, S.; Anthoff, D.; Rose, S.; Tol, R.S.J. The marginal damage costs of different greenhouse gases: An application of FUND. Economics 2014, 8, 1-33. [CrossRef]

76. Álvarez-Chávez, C.R.; Edwards, S.; Moure-Eraso, R.; Geiser, K. Sustainability of bio-based plastics: General comparative analysis and recommendations for improvement. J. Clean. Prod. 2012, 23, 47-56. [CrossRef]

77. Holland, M.; Spadaro, J.; Misra, A.; Pearson, B. Costs of Air Pollution from European Industrial Facilities 2008-2012-An Updated Assessment; EEA Technical report No 20/2014; Publications Office of the European Union: Luxembourg, 2014.

78. Bickel, P.; Friedrich, R. ExternE: Externalities of Energy: Methodology 2005 Update; Office for Official Publications of the European Communities: Luxembourg, 2004; ISBN 9279004239.

79. Beccali, M.; Cellura, M.; Iudicello, M.; Mistretta, M. Resource consumption and environmental impacts of the agrofood sector: Life cycle assessment of italian citrus-based products. Environ. Manag. 2009, 43, 707-724. [CrossRef]

80. Qi, Y.; Yang, X.; Pelaez, A.M.; Huerta Lwanga, E.; Beriot, N.; Gertsen, H.; Garbeva, P.; Geissen, V. Macroand micro- plastics in soil-plant system: Effects of plastic mulch film residues on wheat (Triticum aestivum) growth. Sci. Total Environ. 2018, 645, 1048-1056. [CrossRef]

81. Girgenti, V.; Peano, C.; Giuggioli, N.R.; Giraudo, E.; Guerrini, S. First results of biodegradable mulching on small berry fruits. Acta Hortic. 2012, 926, 571-576. [CrossRef]

82. Almenar, E.; Samsudin, H.; Auras, R.; Harte, B.; Rubino, M. Postharvest shelf life extension of blueberries using a biodegradable package. Food Chem. 2008, 110, 120-127. [CrossRef]

83. Van der Harst, E.; Potting, J.; Kroeze, C. Multiple data sets and modelling choices in a comparative LCA of disposable beverage cups. Sci. Total Environ. 2014, 494, 129-143. [CrossRef]

84. Hottle, T.A.; Bilec, M.M.; Landis, A.E. Biopolymer production and end of life comparisons using life cycle assessment. Resour. Conserv. Recycl. 2017, 122, 295-306. [CrossRef]

85. Soroudi, A.; Jakubowicz, I. Recycling of bioplastics, their blends and biocomposites: A review. Eur. Polym. J. 2013, 49, 2839-2858. [CrossRef]

86. Asiedu, Y.; Gu, P. Product life cycle cost analysis: State of the art review. Int. J. Prod. Res. 1998, 36, 883-908. [CrossRef] 
87. Meeks, D.; Hottle, T.; Bilec, M.M.; Landis, A.E. Compostable biopolymer use in the real world: Stakeholder interviews to better understand the motivations and realities of use and disposal in the US. Resour. Conserv. Recycl. 2015, 105, 134-142. [CrossRef]

88. Changwichan, K.; Silalertruksa, T.; Gheewala, S.H. Eco-efficiency assessment of bioplastics production systems and end-of-life options. Sustainability 2018, 10, 952. [CrossRef]

89. Benoît-Norris, C.; Vickery-Niederman, G.; Valdivia, S.; Franze, J.; Traverso, M.; Ciroth, A.; Mazijn, B. Introducing the UNEP/SETAC methodological sheets for subcategories of social LCA. Int. J. Life Cycle Assess. 2011, 16, 682-690. [CrossRef]

90. Ahmed, T.; Shahid, M.; Azeem, F.; Rasul, I.; Shah, A.A.; Noman, M.; Hameed, A.; Manzoor, N.; Manzoor, I.; Muhammad, S. Biodegradation of plastics: Current scenario and future prospects for environmental safety. Environ. Sci. Pollut. Res. 2018, 25, 7287-7298. [CrossRef] [PubMed]

91. Comăniţă, E.-D.; Hlihor, R.M.; Ghinea, C.; Gavrilescu, M. Occurrence of plastic waste in the environment: Ecological and health risks. Environ. Eng. Manag. J. 2016, 15, 675-685. [CrossRef]

92. Herbes, C.; Beuthner, C.; Ramme, I. Consumer attitudes towards biobased packaging-A cross-cultural comparative study. J. Clean. Prod. 2018, 194, 203-218. [CrossRef]

93. Wageningen University. Biobased Food Packaging through the Eyes of the Consumer. Available online: https://www.wur.nl/en/article/Biobased-food-packaging-through-the-eyes-of-the-consumer.htm (accessed on 22 February 2019).

(C) 2019 by the authors. Licensee MDPI, Basel, Switzerland. This article is an open access article distributed under the terms and conditions of the Creative Commons Attribution (CC BY) license (http://creativecommons.org/licenses/by/4.0/). 